International Journal of Instruction e-ISSN: 1308-1470 • www.e-iji.net
April $2017 \bullet$ Vol.10, No.2

p-ISSN: 1694-609X

pp. $103-118$

Received: 17/01/2017

Revision: 19/02/2017

Accepted: 25/02/2017

\title{
Teacher Training in Myanmar: Teachers' Perceptions and Implications
}

\author{
Mark B. Ulla
}

Walailak University Language Institute, Walailak University, Nakhon Si Thammarat, Thailand, mark.ulla1985@gmail.com

The British Council introduced the English for Education College Trainers (EfECT) Project in Myanmar. This program aims to improve the English language proficiency and teacher training methodologies of all state teacher trainers. Thus, the purpose of this study was to investigate teacher perceptions and attitudes towards this program. The methods used to collect the data were modified questionnaire, focus group discussions and class observation. Based on the findings, teachers reported that they had opportunities to interact with English speaking teachers, could practice their English skills and learned student-centered teaching methodologies. Some issues and challenges that they noted included lack of time for preparation, missing some sessions due to other responsibilities, having poor listening skills and pronunciation, and difficulty adapting to communicative learning and teaching styles. The implication of this study is for policy makers and educational organizations to support local teachers and help them become better teachers in the country.

Key Words: teacher training, teachers' perceptions, program implication, Myanmar teachers, language proficiency, teachers' trainees

\section{INTRODUCTION}

When considering educational reform in any country, but in particular, a developing nation such as Myanmar, several key points as to the importance of teacher training can be taken from the literature. First, it is important for all teachers to be updated with current trends in teaching (Steadman, 2008); so that they will be well-equipped and better qualified to provide their students the necessary skills and knowledge needed for their future career (Supriatna, 2015). Next, training the teachers in how to be proficient in using the English language in the classroom should also be considered (Simon, 2013) because teachers who have a low level of English proficiency most likely tend to resort to more conventional passive and teacher-centered methods of classroom teaching. Lastly, to send competent students to university, teachers in the primary and secondary schools should be trained in how to teach their students using different student-centered methodologies and teaching strategies (Simon, 2013). It should be noted that the terms like "training", and "trainers" are constantly used in this study as they are relevant to the 
ASEAN region context and are also used by previous studies by some researchers in the region.

In ASEAN communities, the capacity to train teachers has always been a challenge because of the lack of qualified trainers to train other teachers and the "overabundance of low-level training" (Weil, 2013). For this reason, a few countries have created teacher-training programs or centers. For example, because English teachers in Vietnam have qualifications which are far below the Ministry of Education and Training required teaching standard (Nguyen, 2015; Nguyen \& Thuy 2015), some teacher training centers and universities in Vietnam have been established and designated to train the local teachers and to improve their teaching qualifications (Dudzik \& Nguyen 2015). Similarly, in Indonesia, a faculty development program for pre-service teachers was also created to upgrade teacher qualifications (Widiati \& Hayati, 2015). Hall (2015) also described the formation of professional development for teachers in Malaysia as a drive towards a quality improvement of the English language teachers in government schools.

Myanmar has been undergoing a major political and economic shift which has impacted education. Education reform has so far concentrated on teacher training as the Ministry of Education, which is responsible for hiring, placing, and promoting qualified teachers in the country, has been providing pre-service and in-service teacher training since 2004 (Ministry of Education, 2004). Although teacher training programs are provided by the government and other educational institutions, some of these are not viewed as effective since the trainers themselves have had no formal training.

Weil (2013) described the nature of the current educational system in Myanmar as highly centralized and top-down because, since there are different ministries that oversee different colleges and universities, higher education lacks the autonomy to stand on its own. Due to this complex educational system, Weil (2013) further commented that Myanmar's ability to hold different professional development and training programs in education and research may be restricted. Likewise, Hayden and Martin (2013) also confirmed that education in Myanmar has been in a much-weakened state due to economic difficulties in the last few decades. This is evident in its poor classroom buildings, conventional teaching methods, and lack of professional development training among its teachers Hayden and Martin (2013). Thus, in order to rebuild the higher education capacity of the country (Goodman, 2013), these problems are gradually being addressed and are now receiving greater attention. Myanmar has begun to collaborate with the USA, the UK and other organizations such as the US Institute of International Education (IIE) (Goodman, 2013), the British Council, and Japan International Cooperation Agency (JICA) to improve its education system. These changes indicate higher interest in teacher training and strengthening the English language skills of state teacher trainers.

One program aimed at improving the quality of education through its teachers in Myanmar has been the English for Education College Trainers (EfECT) project of the British Council Myanmar, funded by the UK Department for International Development (DFID) and the British Council. It aimed to improve the quality of education by delivering language proficiency and methodology training across primary, secondary 
and tertiary schools of Myanmar. The project ran for two years, from August 2014 to August 2016. The first year of the project (August 2014-August 2015) was focused on improving the language proficiency of all state teachers in the country by emphasizing speaking and listening skills along with basic grammar. The second year (September 2015-August 2016) concentrated fully on different child-centered teaching methodologies where classroom observations and teaching assessments were done. The teachers who participated in the EfECT program received language proficiency training for two hours every day except every Wednesday and Friday, when they only had an hour of the program. In a week, they had to complete eight hours of training. This present study thus aims to find out the teacher trainees perceived confidence on the use of the English language, their perceptions on the teacher training program, including the challenges and problems encountered in order to shed light for more teacher trainings in Myanmar.

\section{LITERATURE REVIEW}

Previous studies have investigated teachers' professional development, the teacher's role, and the effects of teacher training programs. However, there are none which include teachers' perceived confidence on the use of the English language in and out of the classroom; their perceptions with regards to teacher training and its implications in the Myanmar context. For example, one study by Nguyen (2015) focused on the differences between her own Vietnamese university teacher training model and those of other Vietnamese universities. Since teachers are only trained by teacher training institutions which are poorly equipped, Nguyen suggested some solutions to improve the quality of teacher training; new child-centered teaching methodologies, and interactive and engaging classroom activities is one of those. Similarly, Supriatna (2015) discussed teacher training issues and challenges in Indonesia and found that the current training program for teachers is ineffective and disorganized. Because of this, a school-based teacher training program was suggested at the provincial level. A similar study was done by Jamil, Razak, Raju, and Mohamed (2015) in Malaysia where they also described teacher training development including issues and challenges in that country. It was found that Malaysia already has a good system of teacher training since its government was interested on improving the quality of its education system. However, it seemed that only a few qualified teachers were in the teaching profession. Thus, the government has improved its teacher remuneration package as well as promotion opportunities to attract better teachers.

Lingam (2012) made a study on teachers' perceptions regarding the training program in Vanuatu Institute of Teacher Education. She found that teachers held a positive view about the training they attended. It was also revealed in her study that some teachers were concerned about the improvement of some issues that were noted in the teachers' training program. Another study on teacher trainees' perceptions and attitudes towards training program was also done by Nenty, Moyo, \& Phuti (2015). It was revealed in their study that teacher trainees had perceived effectiveness in the training program conducted. They stated further that the higher the "teachers' perception of teaching as a profession, the higher is their attitude towards their teacher training program as well as 
towards teaching". Lastly, Kagoda \& Sentongo (2015) in their study on "Practicing Teachers' Perceptions of Teacher Trainees", recommended that teacher trainees should receive more support and guidance from their department heads and subject area coordinators as to the subject matter that should be taught in class. This is for the teacher trainees to master the lesson in the classroom.

On the other hand, a study on teachers' attitudes and confidence was conducted by Brown (2014). However, the study was only focused on technology teacher training whether it affects teachers' confidence on the use of technology and to integrate it in the classroom. It was found that technology training had a positive effect on teachers' confidence on the use of technology in the classrooms. Jung, Cho, \& Ambrosetti (2011) also conducted a study on "Pre-service Teachers' Confidence Levels in Working with Students with Special Needs". The study concentrated only on pre-service teachers and not on the in-service teachers. The results revealed that teachers in special education had a higher confidence to work with special students than those of elementary or secondary teacher. Likewise, secondary teachers also had a higher confidence than those of elementary teachers. Another study on teachers' confidence, feelings and attitudes was conducted by Gatt, \& Karppinen (2014). However, the respondents in their study were primary student teachers. Their findings revealed that teachers training had positive effects on the student-teachers level of confidence towards the teaching of arts and crafts.

This study will explore and discuss the views of Myanmar teachers on the teachertraining and English proficiency program in Myanmar, including issues and challenges. It is hoped that the results of this study will be useful to policy makers in the Ministry of Education in making informed decisions about teacher training programs. Thus, this study proposes the following questions:

1. What is the perceived confidence of these participating teachers in using English now that they are in the training program of the British Council's EfECT project?

2. What are the participating teachers' views about the current teacher training and language proficiency program?

3. What are the issues and challenges faced by the teachers participating in the language training program and the current teaching situation in their respective classes?

\section{METHOD}

For this study, a combined quantitative-qualitative design was adopted. That is, it was conducted in a natural setting, a university in Myanmar, and made plentiful use of understanding through verbal narratives and observations, and flexible designs as Creswell (2003) put it. It is quantitative-qualitative because it involved the use of frequency count and percentage in analyzing the survey questionnaire of the participating teacher-respondents. However, high statistical instruments were not used in the study. Then, analysis proceeded with the tabulation and identification of the responses found in the questionnaire. 


\section{Participants}

Since this research involves teachers as respondents, their names, and other personal information were kept anonymously for ethical considerations. Participants were given a consent form and were made to sign it if they wanted to take part in the study. They were made aware of the purpose of the research, that their participation in the study was voluntary, and that all the information would be treated with utmost confidentiality. Likewise, a letter of permission stating the purpose of the conduct of this study was also sent to the British Council's EfECT management and the head of the university.

There were 51 participants in the study: 37 primary school teachers, and 14 university professors and lecturers. Four additional teachers in the teacher training project did not participate in the study because they took a leave of absence at the time the study was conducted. Likewise, one university English teacher who acted as the translator during the survey and focus group discussion was also excluded from the participants of the study. There were 49 female and two male respondents. The participants taught different subjects in university and primary schools in Myanmar. Six university lecturers held doctorates, and eight held master's degrees. The primary teachers were doing coursework toward their Masters in Education degrees during this time.

The participants were grouped in two different levels according to the Common European Framework of Reference for Languages (CEFR); Elementary (A2), and Preintermediate (B1), according to their scores on the Aptis test, a computer test on grammar, vocabulary, and language skills (speaking, writing, reading and listening). They took the test in June-July 2014 before the training program began in August 2014. They took the same test again after the first year of the project but before the second year of the project began in August 2015. The purpose was to determine the level of English proficiency and to track the progress made in the first year of the training. It was expected that when the training program ended, the teacher-trainees would move one step higher from their current CEFR language proficiency level.

This study was conducted at a university in Myanmar where the English for Education College Trainers (EfECT) project of the British Council Myanmar was held. The researcher was one of the teacher-trainers who taught and trained these 51 teachers on English proficiency and teaching methodologies. He trained three groups of teachers: one class of elementary-level teachers and two classes of pre-intermediate level teachers.

\section{Tools and Procedure}

The data for this study was collected between May 2015 and July 2015 and was taken from a questionnaire, a focus group discussion, and classroom observations. The questionnaire was a modified survey questionnaire from which the original was designed by the project team. The questionnaire made use of one survey question with eight indicators, all written in English. (The original questionnaire had four questions with five indicators written both in the English and Burmese languages.) These indicators evaluated the respondents' level of confidence in using the English language. The responses were shown in emoticons along with written descriptions to provide a clear 
understanding of the response terms used. Assistance from one Burmese university English speaker lecturer was sought. She explained to the participating teacherrespondents in the Burmese language some difficult English words in the questionnaire. This teacher was then excluded from the study.

Both the questionnaire and the focus group discussion were conducted in a two-hour session. First, the respondents answered the questionnaire individually and anonymously for 30 minutes. Then they were grouped into ten five- or six-member groups for a focus group discussion. They met for 30 minutes with a moderator (the researcher) and discussed problems using English and the need for using it, their perceptions of English teaching, the training program, and their experiences teaching in Myanmar classrooms/schools. The teacher trainees presented a summary of their group's ideas the following meeting which lasted for an hour. Each group was given 10 minutes for their presentation. They also presented some suggested solutions and give recommendations to the issues and challenges noted during the focus group discussion.

Lastly, 40-minute classroom lessons were observed by the researcher for the eight university lecturers' classes which were taught in English (math, physics, biology, English, and chemistry). (The remaining six university lecturers who taught the Myanmar language and Myanmar history were excluded from the class observations.) Classroom observations for the 37 primary teachers were done during their program training session. The focus of the class observations was to see how these trainees conducted their lessons using English as a medium of instruction, to measure their confidence in using English, and to evaluate the extent of their ability to conduct classes in English. Classroom management, teaching techniques, and classroom activities were not part of the observation. "Drawing by lots" was employed to determine the order of the teaching demonstrations.

\section{FINDINGS}

Findings (from the survey questionnaire, focus group interview, and classroom observations) are presented in this section.

The first problem on this present study, the perceived confidence of these participating teachers in using English now that they are in the training program of the EfECT project in terms of (a) classroom discussion, (b) conversations with colleagues, (c) talking to other people/foreigners outside the classroom, and (d) writing academic papers can be seen in the survey questionnaire presented below.

\section{Survey Questionnaire}

As can be seen from Table 1, the questionnaire presented one question with eight indicators and their responses on the use of English both in and out of the classroom. All the indicators in the table pertained to the level of confidence in using the English language in speaking, writing, explaining concepts, presenting output, talking to foreigners, giving short talks, and talking to colleagues. 
For the purposes of this analysis, the percentages for very confident and quite confident have been combined; as have those for not very confident and not at all confident. These percentages are shown in Table 1 and are contrasted with average confidence.

Table 1

The combined percentages for very and quite confident and for not very and not at all confident.

\begin{tabular}{|c|c|c|c|}
\hline $\begin{array}{l}\text { (Question): How confident are you in using the } \\
\text { English language now that you are in the } \\
\text { training program of the EfECT project? }\end{array}$ & \multicolumn{3}{|c|}{ Responses } \\
\hline Item (Indicators) & $\begin{array}{l}\text { Very/Quite } \\
\text { Confident }\end{array}$ & $\begin{array}{l}\text { Average } \\
\text { Confidence }\end{array}$ & $\begin{array}{l}\text { Not Very/Not at } \\
\text { All Confident }\end{array}$ \\
\hline $\begin{array}{l}\text { 1. I can use English language as my medium of } \\
\text { instruction in the classroom. }\end{array}$ & $25.49 \%$ & $66.67 \%$ & $7.84 \%$ \\
\hline $\begin{array}{l}\text { 2. I can explain the concepts clearly using } \\
\text { English language to my students. }\end{array}$ & $13.72 \%$ & $76.48 \%$ & $9.80 \%$ \\
\hline 3. I can talk to my colleagues using English. & $47.06 \%$ & $41.18 \%$ & $11.76 \%$ \\
\hline $\begin{array}{l}\text { 4. I can give short talks or presentations on } \\
\text { classroom and academic topics to my } \\
\text { colleagues using English. }\end{array}$ & $41.18 \%$ & $49.02 \%$ & $9.80 \%$ \\
\hline $\begin{array}{l}\text { 5. I can talk to foreigners and other people } \\
\text { anywhere in English. }\end{array}$ & $9.8 \%$ & $52.94 \%$ & $37.26 \%$ \\
\hline $\begin{array}{l}\text { 6. I can pronounce English clearly so that other } \\
\text { people can understand me. }\end{array}$ & $17.65 \%$ & $52.94 \%$ & $29.41 \%$ \\
\hline $\begin{array}{l}\text { 7. I can explain clearly some concepts, and } \\
\text { ideas in writing using English }\end{array}$ & $33.33 \%$ & $49.02 \%$ & $17.65 \%$ \\
\hline $\begin{array}{l}\text { 8. I can write compositions and other academic } \\
\text { writings in English. }\end{array}$ & $17.65 \%$ & $68.62 \%$ & $13.73 \%$ \\
\hline
\end{tabular}

It can be seen that almost all of the items had the highest responses under average confidence, which clearly shows that majority of the respondents already have the confidence to use the English language but still have some reservations about using it outside or in the classroom. For example, $66.67 \%$ of the respondents said that they could use the English language as their medium of instruction in the classroom, while only $25.49 \%$ of the respondents said that they were very confident about using English as a medium of instruction.

Likewise, a majority of the respondents stated that they can explain the concepts clearly using the English language to their students, while only $9.80 \%$ of them stated that they were not confident to explain the concepts in English. This clearly states that the teacher-respondents find both using English as a medium of instruction in the classroom and explaining concepts in English to the students hard. Admittedly, English for them is a foreign language and they were not exposed to English speaking situations where the use of English language is deemed important. This must be the reason why there is still a number of teacher-respondents who perceived that they were not confident in using the English language for classroom instruction. This is also the same result that was found in the recent study of $\mathrm{Vu}$ and Burns (2014) on English as a medium of instruction and the challenges that the tertiary lecturers faced in Vietnam. In their study, it was found that 
that lecturers had difficulty explaining concepts in English, delivering lectures to the students, and answering questions from the students.

On the other hand, it must also be noted that the respondents were very confident to use the English language when talking to their colleagues. As seen in the item number 3, $47.06 \%$ of the respondents stated that they can confidently talk to their colleagues using English, compared with only $9.8 \%$ of the respondents who stated that they could not confidently talk to foreigners and other people anywhere using English. In addition, $49.02 \%$ also of the respondents said that they can confidently give short talks or presentations on classroom and academic topics to their colleagues using English. It only shows that the respondents are only very confident to use the English language when they are talking to their peers and colleagues as they can express themselves and understand each other well.

This perception of the respondents' only shows that talking to colleagues using English is easier than talking to foreigners. The reason for this may be attributed to the fact that talking to foreigners requires a fair level of English to carry out a conversation. Furthermore, talking to colleagues may not be that hard as they know each other already and they have fairly the same level of English proficiency (Elementary level) based on their aptis test. In the focus group discussion, the respondents revealed that speaking English to their colleagues is also their way of practicing the language and they do not care whether they use the language correctly or not since they know and understand each other well. The idea is they get to use the language among themselves confidently.

On the other hand, a majority of the respondents also revealed that their confidence when it comes to talking to foreigners and other people anywhere in English, and pronouncing English clearly so that other people can understand them were on an average level. However, $37.26 \%$ of the respondents also mentioned that they were not confident talking to foreigners and other people anywhere in English. In the focus group discussion conducted, the respondents revealed that this was their first time to have foreign language teachers, and their first time to interactive with English-speaking people. Thus, these teacher-respondents have not been exposed to native speakers and English speaking people until the training program came and their knowledge of the correct sounds and pronunciation of English words is very limited. This made them perceived that they were not very confident to not at all confident when they talk to foreigners and to English speaking people for the fear of not being able to understand and to be understood. This is the reason why these teacher-respondents still need to be exposed to English speaking people and to the sounds of English language.

Lastly, $68.62 \%$ of the respondents revealed that they could write compositions and other academic writings in English at an average level. It can be noted that since these respondents did not have exposure to the English language, and they are used to writing using their Burmese language in most of their time, writing in English is indeed a difficult task for them.

\section{Focus Group Discussion}

The participating teachers' views about the current program through the focus group discussion are presented here. 
To further explore teacher perceptions measured by the questionnaire, a focus group of 51 respondents who were put in a group of ten with five- or six-member was convened to better understand both the positive perceptions of the EfECT teachers' training and the difficulties. Respondents discussed their views, including the issues, challenges, and possible solutions. Two main themes were noted: appreciation and hardships.

\section{Perceptions of EfECT teacher training}

With the EfECT training program, most of the teacher-respondents were glad and thankful that they had the chance to learn English and use it in their everyday communication. All of them expressed their willingness to learn and practice English because this was their first time to be exposed to a native English-speaking teacher.

The issues and challenges faced by the teachers participating in the language training program and the current teaching condition in their respective classes through focus group discussion and classroom observation are presented below.

\section{Issues and challenges}

One important issue about the teacher training program that came up during the focus group discussion was the teachers' tight timetables between their own university classes and the teachers' training sessions. This issue was only true for the university lecturers since they were teaching at the same attending the training program. The primary school teachers were not affected of this since they were full-time master's students of the university. Because of this, some university lecturers missed a number of training sessions in the program while others felt tired from their own classroom teaching, yet they still had to rush to attend the teachers' training session every day.

Another challenge that affected the teachers was their difficulty in adapting to the communicative learning and teaching style since they were not used to this kind of environment. In fact, according to them, they did not have a clear understanding of the concept of non-directive teaching, self-directed study, and other autonomous learning strategies. All these learning techniques were new to them and they were still coping with changes such as how to transform their classrooms from a conventional method of teaching to more student-centered teaching and learning, where there is less teacher talk and students are engaged in authentic and meaningful tasks.

Suggested solutions to issues faced in the training program

Most teacher-trainees suggested and agreed that there should be a method of liaising between the university and the training program management with regards to the timetable. Additionally, pronunciation lessons, intensive listening skill exercises, and Myanmar-context topics should be given more emphasis. Lastly, constant exposure to child/student-centered approaches of teaching should be the topmost priority of the trainers.

\section{Classroom Observations}

The data in Table 1 shows that the teachers' confidence in all items were average since as noted, this was just the first year of the project. Although some participants expressed 
a poor ability in using the English language, especially in oral communication, still the greater percentage was at average confidence. In the classroom observations, two out of 14 university lecturers were not able to use English all throughout their 1-hour classroom teachings. They reverted to their native language to explain and to give illustrations and examples since a number of their students seemed confused about the discussion done in the English language. One lecturer used her native language from time to time. All the other lecturers managed to deliver the lessons in English, although some grammatical and phonetic errors were observed. In fact, even if their students asked a question in their native language, these lecturers always tried to answer them in English.

For the primary teachers who had their classroom observations in the teachers' training classroom, all of the 37 teachers were able to deliver their lessons in English all throughout the allotted 40-minute period. Even if some phonetic and grammatical errors were noted, they were able to give examples and illustrations, and deliver instructions and activities in English.

The findings of the study add to those of previous studies, including Lingam (2012; Nenty et al. (2015), and Kagoda \& Sentongo (2015), showing the perceived positive effects of the teacher training program to the teacher trainees. In this present study and based on the findings, teacher trainees held a positive view of the teacher training conducted in their country as they got to learn some new teaching methodologies and exposed themselves to English-speaking people. This implies that teacher training should be given more emphasis and teachers should be updated with the new trends in teaching for the improvement of the education system in Myanmar.

Likewise, the results of this study also support the findings of Jung et al. (2011), Brown (2014), and Gatt \& Karppinen (2014), on the improved confidence in teaching of the teacher trainees from the teacher training program. The present study showed that teacher trainees had perceived that their level of confidence in teaching using English as a medium of instruction in the classroom improved significantly from not at all confident to average confidence. This shows that with proper training and exposure to English speaking situations, confidence to use the English language both in and out of the classroom can be attained. Therefore, it must be noted that teacher training program is a factor that helps improved the level of confidence of the teachers in using English for communication and instruction.

Admittedly, teacher training is a factor that helps teachers to become more prepared and qualified to teach. Providing teachers with teacher training or opportunities for professional development is indeed necessary. However, in this present study, several issues and challenges were also seen. Although these challenges and issues were different from the previous studies of Supriatna (2015); Simon (2013); Weil (2013); Sunday (2015); Jamil et al. (2015), and McCord (2013), still they posed a greater challenge on the implementation of the teacher training program. This study revealed that teacher trainees faced difficulty adjusting to the new teaching methodologies, and to their tight timetable. This shows that the training program has never been easy on the part of the teacher trainees as they need to cope with and adapt to the changes to the new 
styles and strategies of teaching. According to Jamil, et al (2015), teachers at present face a daunting task since they have to make sure that at the end of every session, students have learned something from what they have been taught. Preparing and delivering good lessons to the students and doing well in the classroom are what teachers expected to perform in the classrooms. Adopting new methods and styles which are different from the usual routines of the teachers in the classrooms require more time for preparation and adjustment which is a challenge that teachers need to cope with.

Generally, the teacher-trainees were glad to be part of the teacher's training program and English language competency building. Although some issues were revealed during the group interviews and discussions, still they were very positive of the result when the program ended. The acknowledgement of some challenges and issues with their suggested solutions in the training program and of the teacher trainees' perceived improvement in confidence in using the English language only imply that teacher training and language proficiency building is what the teachers need. More specifically, this study shows that teacher training and practicum teaching should be given more emphasis by the heads of the universities and colleges of education and support from the government and the Ministry of Education, not just in Myanmar but all countries in ASEAN region. Future studies can be done to investigate the perceptions of the program. Also, researchers may focus on other variables aside from perceptions, issues and challenges such as these are narrow areas of research. Further study on the level of confidence of the teachers as well as their language proficiency should be conducted at the end of the second year of the training program to identify the progress that the teachers make in the training program and to see whether their perceptions of the training program would be changed.

\section{CONCLUSION}

This study was aimed at exploring teachers' perceptions towards the teacher training program and English competency building in Myanmar. Findings revealed that teachers held a positive view of the program as they learned some student-centered teaching methodologies from their trainer. They also perceived that their confidence to use the English language both for communication and for classroom instruction has been greatly improved since they joined the teacher training program. However, the findings were only limited and could not represent the perceptions of all teacher trainees in the training program. Other studies may focus on the training program evaluation from the perspective of other stakeholders such as the program manager, university heads, and the trainers.

Teacher training around ASEAN region is shaping its language education. Since teachers play the most important role in the classrooms, training and improving their language use and teaching methods is a good avenue to prepare them to become better qualified. However, some issues and challenges have to be considered to better understand them and the changes that they have to deal with in the classrooms. Thus, it may be helpful for the Ministry of Education, educational organizations and policy makers in the region to consider some issues and challenges to guide and support the local teachers and help them become better teachers in their country. 


\section{Acknowledgments}

As one of the recipients in 2015 CamTESOL Regional ELT Research Grant, I would like to express my gratitude and heartfelt thanks to CamTESOL, IDP Cambodia, and UECA for the grant and to my research mentor, Mrs. Ragni Prasad (University of Wollongong College, Australia); to my editors Ms. Kathryn Oghigian (Waseda University, Japan), and Ms. Kelly Kimura (Soka University, Japan) for all the help and support.

\section{REFERENCES}

Brown, H. (2014). Teachers attitudes and confidence in technology integration. Theses, Dissertations and Capstones. Paper 893. Retrieved from http://mds.marshall.edu/cgi/viewcontent.cgi?article=1898\&context=etd.

Creswell, J.W. (2003). Research design: Qualitative, quantitative, and mixed approaches. Thousand Oaks, CA: Sage.

Dudzik, D. L., \& Ngoc Nguyen T. (2015). Vietnam: Building English competency in preparation for ASEAN 2015. In R. Stroupe \& K. Kimura (Eds.), ASEAN integration and the role of English language teaching (pp. 14-41). Phnom Penh, IDP Education: Cambodia.

Gatt, I. and Karppinen, S. (2014). An enquiry into primary student teachers' confidence, feelings and attitudes towards teaching arts and crafts in Finland and Malta during initial teacher training. International Journal of Art \& Design Education, 33, 75-87. doi: 10.1111/j.1476-8070.2014.12002.x.

Goodman, A. E. (2013, April). Foreword: making history by investing in the future. Institute of International Education (Eds.), Investing in the future: rebuilding higher education in Myanmar. A briefing paper from IIE's center for international partnerships. New York.

Hall, S. J. (2015). A past before a blueprint: Malaysia's challenges in English language teaching. In R. Stroupe \& K. Kimura (Eds.), ASEAN integration and the role of English language teaching (pp. 122-149). Phnom Penh, IDP Education: Cambodia.

Hayden, M., \& Martin, R. (2013). Recovery of the education system in Myanmar. Journal of International and Comparative Education,2(2). http://crice.um.edu.my/downloads/1Hayden\&Martin.pdf.

Jamil, H., Razak, N.A., Raju, R., \& Mohamed, A.R. (2015). Teacher professional development in Malaysia: Issues and challenges. http://aadcice.hiroshimau.ac.jp/e/publications/sosho4_2-08.pdf.

Jung, W., Cho, G., \& Ambrosetti, D. (2011). Preservice Teachers' Confidence Levels in Working with Students with Special Needs: Improving Preservice Teacher Training Programs. Electronic Journal for Inclusive Education, 2 (7). 
Kagoda, A.M. \& Sentongo, J. (2015). Practicing teachers' perceptions of teacher trainees: Implications for teacher education. Universal Journal of Educational Research 3(2), 148-153. DOI: 10.13189/ujer.2015.030211.

Lingam, G. I. (2012). Beginning teachers' perceptions of their training programme. Scientific Research, 3(4), 439-447. http://dx.doi.org/10.4236/ce.2012.34068.

McCord, C. (2013, April). Recommendations to support partnerships and exchanges. Institute of International Education (Eds.), Investing in the future: Rebuilding higher education in Myanmar. A briefing paper from IIE's center for international partnerships. New York.

Ministry of Education. (2004, September). Development of education in Myanmar http://www.ibe.unesco.org/National_Reports/ICE_2004/myanmar_ocr.pdf ret March 23, 2015.

Nguyen C. T. (2015). Training high qualified teachers in Vietnam: Challenges and policy issues. http://aadcice.hiroshima-u.ac.jp/e/publications/sosho4_2-16.pdf.

Nguyen, T. P., \& Thuy P. P. (2015). Innovation in English language education in Vietnam for ASEAN 2015 integration: Current issues, challenges, opportunities, investments, and solutions. In R. Stroupe \& K. Kimura (Eds.), ASEAN integration and the role of English language teaching (pp. 89-104). Phnom Penh, IDP Education: Cambodia.

Nenty, et.al., (2015). Perception of teaching as a profession and UB teacher trainees' attitude towards training programme and teaching. Educational Research and Reviews. Vol. 10(21), pp. 2797-2805. DOI: 10.5897/ERR2015.2441.

Simon, D. (2013, April). Needs in the higher education sector. Institute of International Education (Eds.), Investing in the future: Rebuilding higher education in Myanmar. A briefing paper from IIE's center for international partnerships. New York.

Steadman, J. (2008). Teacher training: Systemic issues and challenges. ZOA issue paper no.3. Mae Sot, Thailand: ZOA Refugee Care Thailand. Retrieved March 2015 http://www.burmalibrary.org/docs12/ZOA-Issue_paper_No_3-Steadman.pdf.

Sunday, A. F. (2015). Management of teacher education in Nigeria: Issues, problems andremedies.http://www.deta.up.ac.za/archive2007/presentations/word/Management\%2 0of $\% 20$ teacher $\% 20$ education $\% 20$ in $\% 20$ Nigeria $\% 20$ Issues $\% 20$ and $\% 20$ problems $\% 20 \%$ 20Akiwumi\%20Femi\%20Sunday.pdf.

Supriatna, A. (2015). Indonesia's issues and challenges on teacher professional development. http://aadcice.hiroshima-u.ac.jp/e/publications/sosho4_2-04.pdf

Vu, N.T., \& Burns, A. (2014). English as a medium of instruction: Challenges for vietnamese tertiary lecturers. The Journal of Asia TEFL, 11(3),1-31.

Weil, C. (2013, April). The current political and higher education context in Myanmar. Institute of International Education (Eds.), Investing in the future: Rebuilding higher 
education in Myanmar. A briefing paper from IIE's center for international partnerships. New York.

Widiati, U., \& Hayati, N. (2015). Teacher professional education in Indonesia and ASEAN 2015: Lessons learned from English language teacher education programs. In R. Stroupe \& K. Kimura (Eds), ASEAN integration and the role of English language teaching (pp. 105-121). Phnom Penh, IDP Education: Cambodia.

\section{Turkish Abstract Myanmar'da Öğretmen Eğitimi: Öğretmenlerin Algıları ve Öneriler}

İngiliz Konseyi, Myanmar'da bir İngilizce Eğitim Programı Projesi (EfECT) başlatmıştır. Bu programın amacı bütün eyaletteki eğitim uzmanlarının öğretmen eğitim yöntemlerini ve İngilizce uzmanlığını geliştirmektir. Bu çalışma öğretmenlerin bu proje ile ilgili algılarını ve tutumlarını araştırmayı amaçlamıştır. Veri toplamak için modifiye edilmiş anket formu, odak grup görüşmeleri ve sınıf gözlemleri kullanılmıştır. Bulgulara göre, öğretmenler İngilizce konuşan öğretmenlerle etkileşime girme firsatı bulduklarını, İngilizce becerileri konusunda uygulama yaptıklarını ve öğrenci merkezli öğretim yöntemlerini öğrendiklerini belirtmişlerdir. Öğretmenler ayrıca ,bu yöntemle öğrenmeye hazırlanmak için zaman bulamadıkları, bazı oturumları diğer sorumlulukları yüzünden kaçırdıklarını; dinleme ve telaffuzda eksiklerinin olduğunu; öğretim stilleri ve iletişimsel öğrenmeye uyum konusunda zorluklar yaşadıklarını not etmişlerdir. $\mathrm{Bu}$ çalışma kanun yapıcılara ve eğitim organizasyonlarından sorumlu kişilere yerel bölgelerde çalışan öğretmenleri desteklemeyi ve onlara ülkelerinde daha iyi öğretmenler olmaları için destek olmalarını tavsiye etmektedir.

Anahtar Kelimeler: öğretmen eğitimi, öğretmen algıları, program tavsiyeleri, Myanmar öğretmenleri, dil uzmanlığı, öğretmen eğitimi

\section{French Abstract}

Professeur Recevant une formation dans le Myanmar : les Perceptions de Professeurs et Implications

Le British Council a présenté l'anglais pour des Entraîneurs de Collège d'Enseignement (EfECT) le Projet dans le Myanmar. Ce programme a pour but d'améliorer la compétence de langue anglaise et le professeur formant les méthodologies de tous les entraîneurs(formateurs) de professeur d'état. Ainsi, le but de cette étude était d'examiner des perceptions de professeur et des attitudes vers ce programme. Les méthodes ont eu l'habitude de se rassembler(de prendre) les données étaient le questionnaire modifié, des discussions de groupe de discussion et l'observation de classe. Basé sur les découvertes, les professeurs ont rapporté qu'ils avaient des occasions d'interagir avec l'anglais parlant des professeurs, pourraient pratiquer leurs compétences anglaises et ont appris des méthodologies d'enseignement centrées sur étudiant. Quelques questions et défis qu'ils ont noté le manque inclus de temps pour la préparation, manquant(regrettant) quelques sessions en raison d'autres responsabilités, ayant des qualités d'écoute pauvres et la prononciation et la difficulté s'adaptant à l'apprentissage communicatif et des styles d'enseignement. L'implication de cette étude est pour des décideurs et des organisations éducatives pour supporter des professeurs locaux et les aider à devenir de meilleurs professeurs dans le pays.

Mots Clés: la formation de professeur, les perceptions des professeurs, programme l'implication, le Myanmar Des professeurs, la compétence de langue, les stagiaires des professeurs 


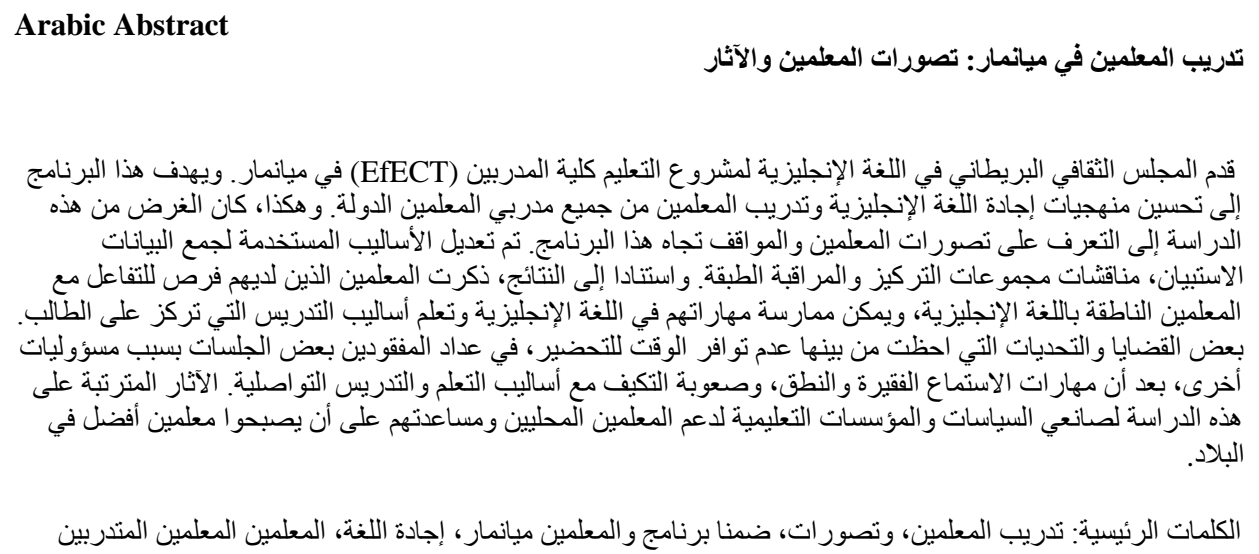

\section{German Abstract}

\section{Lehrerausbildung in Myanmar: Wahrnehmungen und Implikationen der Lehrer}

Der British Council führte die englische für Bildung College Trainer (EfECT) Projekt in Myanmar. Dieses Programm zielt darauf ab, die Englischkenntnisse und Lehrerausbildungsmethoden aller staatlichen Lehrerausbilder zu verbessern. Der Zweck dieser Studie war es, die Lehrerwahrnehmungen und Einstellungen zu diesem Programm zu untersuchen. Die Methoden zur Erhebung der Daten wurden modelliert Fragebogen, Fokus Gruppendiskussionen und Klassenbeobachtung. Basierend auf den Ergebnissen, berichteten die Lehrer, dass sie Möglichkeiten hatten, mit englischsprachigen Lehrern zu interagieren, ihre englischen Fähigkeiten ausüben und lernen, Schüler-zentrierte Lehrmethoden. Einige Fragen und Herausforderungen, die sie feststellten, beinhalteten Mangel an Zeit für die Vorbereitung, fehlten einige Sitzungen aufgrund anderer Verantwortlichkeiten, mit schlechten Hörverständnis und Aussprache und Schwierigkeiten, sich an kommunikatives Lernen und Unterrichtsstile anzupassen. Die Implikation dieser Studie ist für politische Entscheidungsträger und Bildungsorganisationen, um lokale Lehrer zu unterstützen und ihnen zu helfen, bessere Lehrer im Land zu werden.

Schlüsselwörter: lehrerausbildung, wahrnehmung der lehrer, programmimplikation, MyanmarLehrer, sprachkenntnisse, lehrerauszubildende

\section{Malaysian Abstract Latihan Guru di Myanmar: Persepsi dan Implikasi Guru}

British Council memperkenalkan Bahasa Inggeris untuk Projek Pendidikan College Trainers (EfECT) di Myanmar. Program ini bertujuan untuk meningkatkan latihan dan kemahiran Bahasa Inggeris semua pelatih guru negeri. Oleh itu, tujuan kajian ini adalah untuk mengkaji persepsi 
guru dan sikap mereka terhadap program ini. Kaedah yang digunakan untuk mengumpul data telah diubah suai menggunakan soal selidik, perbincangan kumpulan fokus dan pemerhatian kelas. Berdasarkan kajian ini, guru-guru melaporkan bahawa mereka mempunyai peluang untuk berinteraksi dengan guru-guru berbahasa Inggeris, boleh mengamalkan kemahiran bahasa Inggeris mereka dan belajar kaedah pengajaran berpusatkan pelajar. Beberapa isu dan cabaran yang mereka menyatakan termasuk kekurangan masa untuk penyediaan, hilang beberapa sesi kerana tanggungjawab lain, yang mempunyai kemahiran mendengar kekurangan dan sebutan, dan kesukaran menyesuaikan diri dengan gaya pembelajaran dan pengajaran komunikatif. Implikasi kajian ini adalah untuk pembuat dasar dan organisasi pendidikan untuk menyokong guru tempatan dan membantu mereka menjadi guru yang lebih baik di negara ini.

Kata Kunci: latihan guru, persepsi, program implikasi, guru Myanmar, penguasaan bahasa, guru guru pelatih

\section{Russian Abstract \\ Подготовка Учителей в Мьянме: Восприятие Учителями и Их Последствия}

Британский Британский совет представил проект “Английский для образовательных колледжей” в Мьянме. Эта программа направлена на совершенствование английского языка, повышения квалификации учителей и методологий подготовки учителей из всех государственных учреждений. Таким образом, целью данного исследования было расследовать восприятие и отношение учителей к этой программе. Методами, используемыми для сбора данных, были измененный вопросник, обсуждения в фокусгруппах и наблюдение за классами. Основываясь на полученных данных, преподаватели сообщили, что у них есть возможность взаимодействовать с учителями, говорящими на английском языке, они могут практиковать свои знания английского языка и выучить методологии обучения, ориентированные на учеников. Некоторые проблемы и трудности, которые они отметили, включал нехватку времени для подготовки, отсутствие некоторых занятий из-за других обязанностей, имеющий плохое умение слушать и произношение, а также трудность адаптации к стилям коммуникативного обучения и обучения. Смысл этого исследования заключается в том, что директивные органы и образовательные организации оказывают поддержку местным учителям и помогают им стать лучшими учителями в стране.

Ключевые Слова: подготовка учителей, восприятие учителями, последствия для программы, учителя Мьянмы, знание языка, стажеры учителей 